\title{
Pre-service and in-service English teachers' outlook in the use of online learning
}

\author{
Nasrullah \\ Universitas Lambung Mangkurat, Jl. Brigjen H. Hasan Basri, Pangeran, Kec. Banjarmasin Utara, Kota Banjarmasin, Kalimantan Selatan 70123, Indonesia \\ nasrullah01@ulm.ac.id
}

\section{ARTICLE INFO}

\section{Article history}

Received 12 December 2019

Revised 14 March 2020

Accepted 4 August 2020

Available online, 15 January 2021

Keywords

learning tools

online Learning

pre-service

in-service English teachers

\section{ABSTRACT}

The advancement of technology by the emergence of various websites and applications in learning English is inevitably becoming phenomena today. However, many educators especially in-service teachers in Asian secondary schools are reluctant to embody them in the process of English Language Teaching (ELT) since this problem has existed in last decade in the English speaking countries which place English as first and second language; one emerging factor might likely be the status of either $\mathrm{x}$ generations or millennial generation attached to some of them in coin with digital native or digital immigrant as proposed by Marc Prensky. Therefore, this paper is supposed to explain an investigation on the view shown by both sides (pre-service and in-service English teacher). In doing so, a qualitative approach is conducted by involving five pre-service teachers and five in-service teachers in South Kalimantan. The expected finding of this research could depict the variety of chosen views towards the insight and knowledge of ELT resources whether it can be useful for the process of pedagogy in the learning process as well as their classroom instruction.

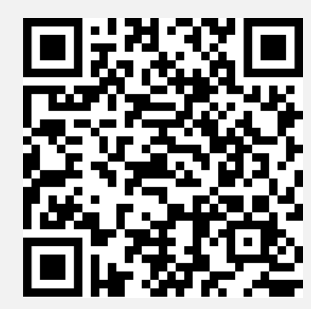

This is an open access article under the CC-BY-SA license.

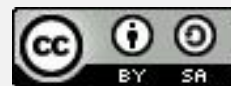

\section{Introduction}

Since instructional activities nowadays no longer reside only by having face to face interaction, online learning takes its mark as one of the means to hold the learning process. There are several definitions to be taken into account when it comes to online learning. While Khan (1997) defined the use of Web to deliver instruction for a remote audience, Carliner (1999) defined it as educational material which is presented via computer (Khan, 2001). As technology is more developed, its definition is also broader, directing to access to learning experiences that provide flexibility and participant interaction (Ally, 2004; Benson, 2002; Carliner, 1999; Conard, 2002). In line with it, the essence of those explanations is the learning process that provides experiences through maximum use of the internet for pedagogical purposes could also be considered in online learning. That's why even online learning has been connected to a complete cycle of the instructional process by using the internet, in a broad sense, the term internet, online, electronic and virtual learning is interchangeable one and another in an array of different contexts of interaction in distance learning.

There have been a larger variety of web-based tools worldwide in the past two decades. Furthermore, applications in play store, web 2.0 tools as web interactive, audio and video editing 
tools that can be used for technical-oriented, online resources or word processing/presentation software tools for work-oriented, social networking tools for social interactive, and gaming consoles which is used to game-oriented are some that can be used for teaching tools. Nevertheless, even if they have been exposed either in or out of pre-service and in-service learning environments, the use of technology or tools still cannot be ensured to exist in the classroom. Therefore, Ash (2011) and Brown \& Warschauer (2006) further commented that educational institutions with a considerable number of technological devices could not guarantee effective integration.

The phenomena above prompt us to trend terms of Digital Native and Digital Immigrant. Since its inception in 2001 as initiated by Prensky (2001), native users of technology which are effortless in the digital language of computers, video games, and the Internet as it is known as digital natives (Prensky, 2005: 8). It is in line with Levine (2010: 20) who mentioned that young people recently either students in schools or the ones who would like to be a teacher in the educational program are classified as digital natives who are surrounded in a world of computers, cell phones, Internet, MP3 players, and social networking. These people are usually called "the Net Generation, Generation Next, Generation M, the Boomerang Generation, and the Digital Natives while another term used is "Millennials" (Dede, 2005; Kane, 2019; Thielfoldt \& Scheef, 2004).

Nevertheless, Digital Natives are relatively novice to the professional workplace recently, and are still in need of mentoring, supervising, regarding experience or confidence (Thielfoldt \& Scheef, 2004). Manzo (2009) added that they need longer than it is thought to be savvy and practical users of online and electronic instructional tools. Moreover, Chen, Lim, and Tan (2010: 637) posited that findings of research of 1554 pre-service teachers born after 1980 found that a gap between daily information communication technology and its integration for teaching and learning still occurs for this age group.

Unlike Digital Natives, Prensky (2001: 1) stated that Digital Immigrants are people who were not born into the digital era, even though some could later apply many aspects of technology and modern tools within a variety of available applications. Toledo (2007: 88) mentioned that Digital Immigrants are constrained with an unknown culture of language, behaviors technology use, and they may encounter a difficult time with the continuous changes that frequently come with technology.

With the abundance of tools and products of technology, the next case is how to make them available in the classroom, to be useful, and become the aid in learning and teaching activities. Guha (2002: 3) posited that knowledge of technology is merely one of the crucial features to a teacher's use of technology in their instructional lives; they also have to learn how to fuse it for teaching and student learning digitally or via online (internet-based). Therefore, before the tangible things which in the form of a feature of learning technology for educational purposes are carried in an instructional context, it is of importance to investigate how pre-service and in-service teachers view them and, hopefully, the mindset of integrations can be overtly faded up.

\section{Research Method}

This study employed a qualitative approach. The interview was used to collect the data of perspectives or views from five pre-service teachers (PS T) and five in-service teachers (IS T). There are 20 questions provided to be asked to both PS T and IS T.

\subsection{Participants}

The participants for this study comprise five pre-service teachers who study in an English language program for three and a half years and five in-service teachers who have been working for more than five years.

\subsection{Situation in Research Setting}

Since the copious technological products reach every corner of place from near to the remote area, the availability of technology today is not only deemed by the existence of computer hardware but also far from that the handily sophisticated ones have been everywhere. Therefore, a handphone with its internet, which provides web, interactive web, and even applications, has been readily accessible for both teachers and students as users. Even so, the availability of technological supports (like Wi-Fi to bridge internet connection through computer set) are still not spread 
proportionally and become the main reason that the teaching process is not relying on technology in the facet of in-service teachers (some live in urban and some in suburban) though not for preservice teachers which taken as participants who reside in urban area.

\section{Results and Discussion}

The findings are discussing the views in the topic the realm of digital literacy, the technological products which become a means of lesson resources are located surrounding them which elaborated into three main points of view: how pre-service and in-service teachers see digital literacy in pedagogical practices, how their perception toward technology advances available nearby, and in what way technology can be integrated into classroom.

Table 1. Pre-Service Teachers

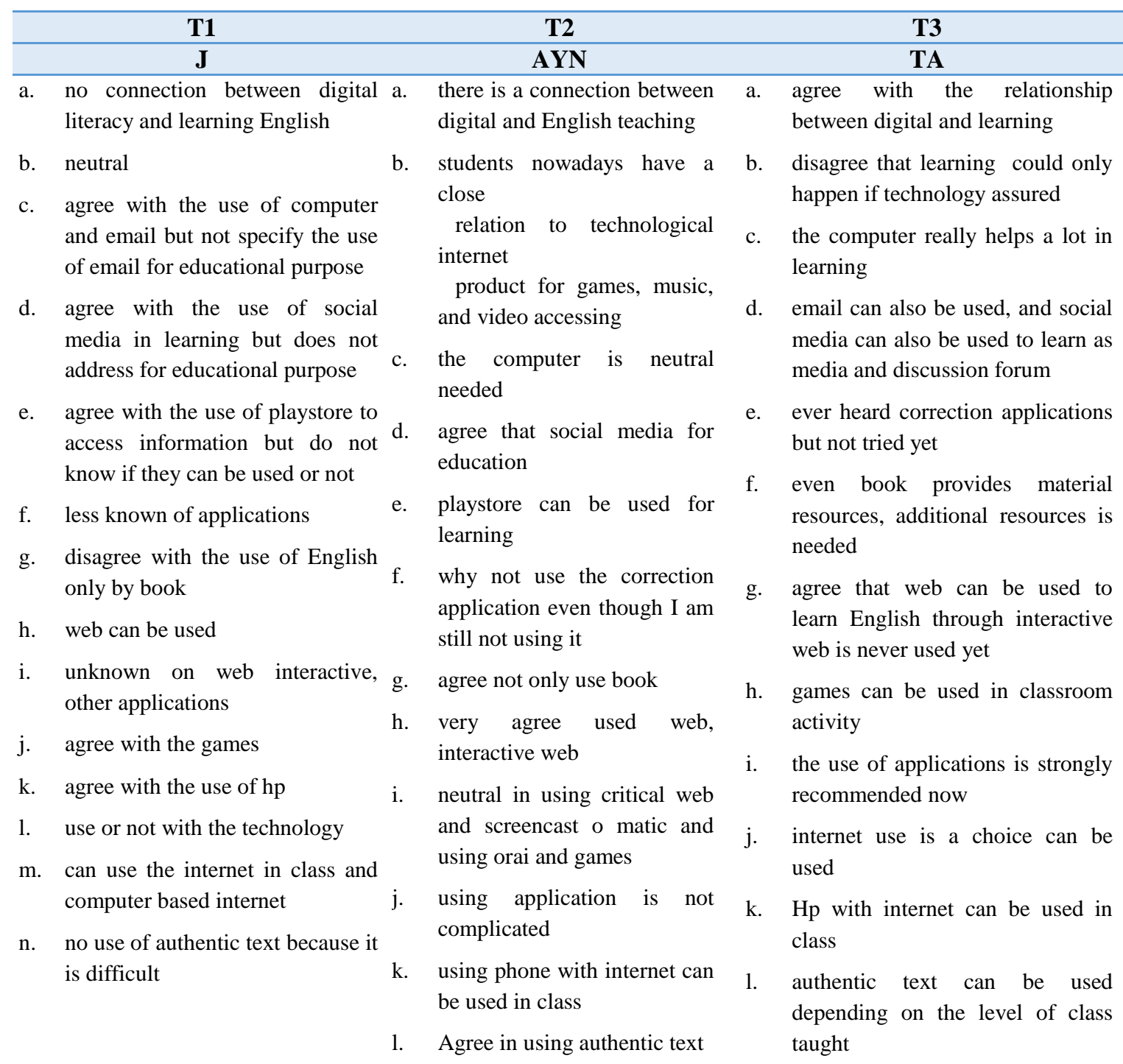

\begin{tabular}{|c|c|}
\hline T4 & T5 \\
\hline SEN & GAF \\
\hline $\begin{array}{l}\text { a. there is a relationship between DL and English learning } \\
\text { because it can help the learning process } \\
\text { b. can use computer and the like and email can be used as } \\
\text { means to learn English } \\
\text { c. social media can also be used to be means of }\end{array}$ & $\begin{array}{l}\text { a. digital literacy can give help for both teacher } \\
\text { and students in the teaching and learning } \\
\text { process } \\
\text { b. that without technology learning still can be } \\
\text { held }\end{array}$ \\
\hline
\end{tabular}




\section{announcement}

d. application can be used as well in learning English

e. application like zip grade etc. can be used in online learning

f. whether by using a book or not, a teacher can lead learning

g. have no idea on the using of screencast o matic

h. good to use the free application provided in smartphones and can make efficient procedures

i. games can be used in teaching activities

j. with or without technology learning can still run

k. internet and com with internet should be allowed to be used in class

1. it is recommended using authentic text for learning English c. the use of computer depending on a user can help the learning process

d. email can be used as a mediator

e. social media can be used for discussion

f. a selected smartphone application can be used to learn English even some have never been tried yet

g. book is enough as a resource to learn

h. web can be used as media to learn a skill in English though I am not keen on using interactive web

i. agree with the use of critical thinking media using

j. never heard screencast o matic

k. orai and turn in really help to learn

1. Games can be used in class in learning process to avoid boredom.

m. use an application to learn is complicated

n. the use of internet is allowed under the condition of teacher instruction

o. even rarely do I use authentic text in learning English, however, I agree with the use of it

Table 2. In-Service Teachers

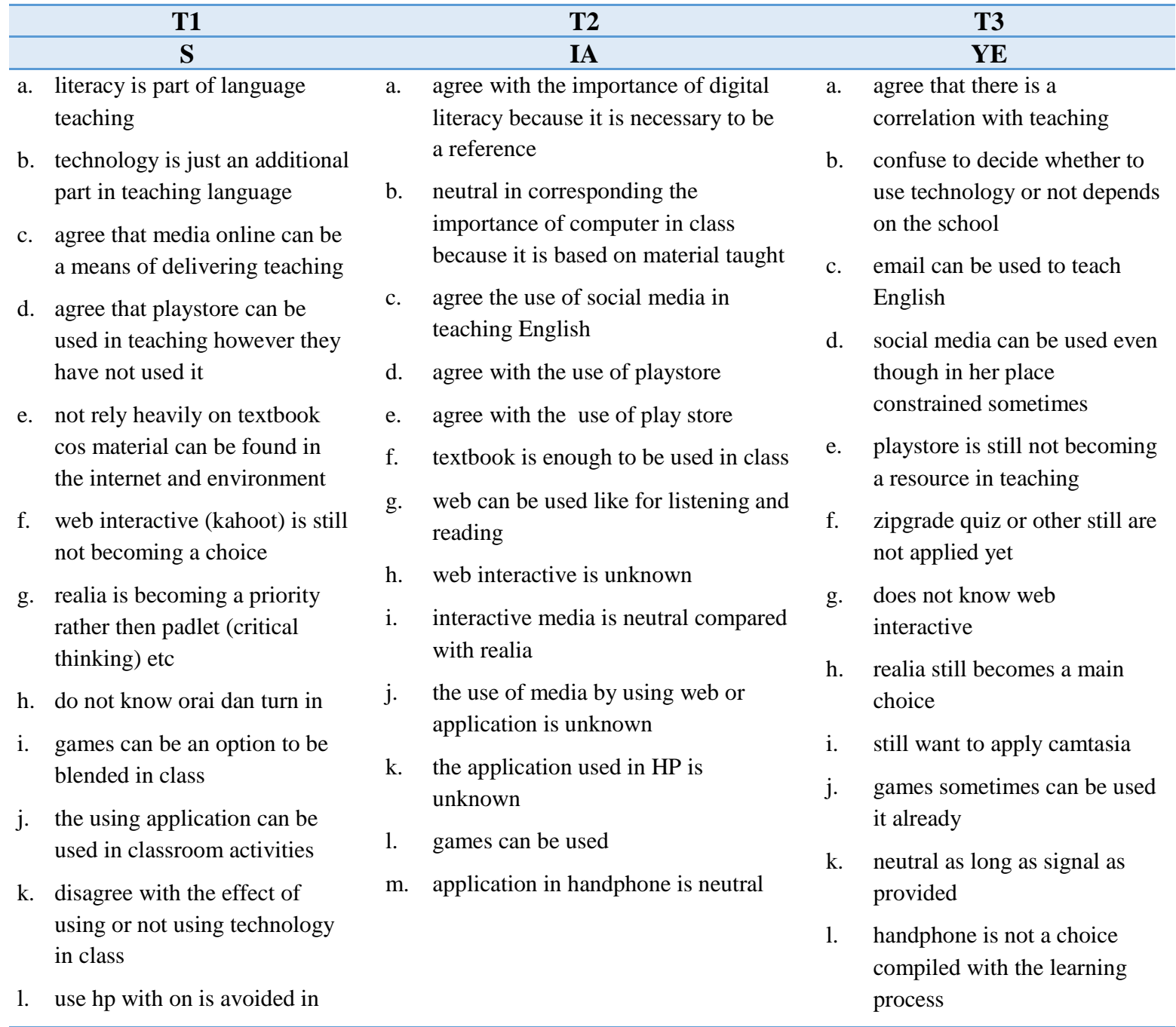




class
m. The use of computer-based on
the internet can still be used
n. authentic text in real
newspaper better avoided used
in class

\begin{tabular}{|c|c|c|}
\hline & T4 & \multirow{2}{*}{$\begin{array}{r}\text { T5 } \\
\text { SI }\end{array}$} \\
\hline \multicolumn{2}{|r|}{$\mathbf{E}$} & \\
\hline a. & $\begin{array}{l}\text { agree that literacy has strong connection to the learning } \\
\text { process }\end{array}$ & $\begin{array}{l}\text { a. agree that there are connection literacy and } \\
\text { teaching process }\end{array}$ \\
\hline b. & $\begin{array}{l}\text { technology really help the English teaching } \\
\text { email can be used in learning English cos no connection }\end{array}$ & $\begin{array}{l}\text { b. even as no technology, the classroom can still } \\
\text { going on }\end{array}$ \\
\hline d. & $\begin{array}{l}\text { even no use of application and website there is still belief } \\
\text { on existence to them }\end{array}$ & $\begin{array}{l}\text { c. can use a computer, email but not use for } \\
\text { educational purpose }\end{array}$ \\
\hline e. & $\begin{array}{l}\text { web sometimes is used to find out information for } \\
\text { teaching }\end{array}$ & d. agree for using playstore but never use it \\
\hline f. & $\begin{array}{l}\text { so support the use of media online but the hindrance of the } \\
\text { obstacle }\end{array}$ & \\
\hline g. & no hp is allowed & \\
\hline h. & internet com is allowed & \\
\hline i. & authentic text is never used & \\
\hline
\end{tabular}

The perspective of pre-service and in-service teachers sees digital literacy (aspect on in online learning) in pedagogical practices

As technology permeates every aspect of our lives, the skill to navigate and accomplish tasks through technology grows. Even the insight of technology varies one and another, the need to understand technology skills is a must. It is based on the fact that many fail to get the best of technology for their use of life: facebook is used to kill time during productive office hours; Whatsapp is used to communicate even while driving, and even online games dominate adolescent lives in wasting their time not to learn but for randomly purposed competing. Thus, it is digital literacy as a specific skill to have safe surfing in a variety of current and future technological product forms.

In relations to insight and knowledge possessed by pre-service teachers, Even there is one PS T opposing others (PST 1), most of the sides covering pre-service teachers (PS T 2, PS T 3, P ST 4 and PS T 5) look at digital literacy have significant relationship to the process of teaching and learning in class. While the overview of IN T (IN T 1, 2, 3, 4, 5) that they share the common belief that there is a tight connection between digital literacy and the teaching and learning process in class. Even though it has not investigated specific types of digital literacy skills that can be applied in the classroom, at least they have a sense that technology surrounding them has a specific impact, sooner or later, to teaching practices.

\subsection{The perception toward technology advances available nearby}

In the discussion toward technology, both pre-service and in-service teachers acknowledge that they are now in the moment and environment that technology has been progressing more rapidly so that the existence of its variants have been available in their lives starting to computer set, email, wireless, internet, web page, padlet up to smartphone with various applications attach to them such as social media applications, interactive web, Zip Grade, Orai, turn in till the other English learning applications.

Concerning knowledge of those technologies, features of view shown by pre-service teachers (PS T 1, 2, 3, 4, and 5) elicit availability of the use of computers, internet, web, applications have been adjoining in their lives. Yet, to function for educational purposes, it is still in different cases, and they need explicit instructional guidance to make them more useful. In the meantime, while the current technological devices have exposed PS Ts, the IS T claims that not all facilities are available their educational milieu like internet facilities connected to computer set provided in 
schools where they work like what has been uttered by IS T3 who said that as long as the connections are exist learning through application can be held easier. Others have also pointed to the other case (IS T1,T2 T4 and T5) that even connection exists; we perceived technologies in a different way of using them rather than for educational purposes. Thus, even so, they believe that technological interventions can make the work much easier imparted in teaching and learning activities.

\subsection{The Existence of Technology in the Classroom}

The interesting thing happens here with the phenomena shown in this study. PS T2 and PS T5 said that he supports the use of correction and making quiz applications like zip grade and quiz creator, but he never applies them. Therefore, what has to happen to PS T1 is that as he is asked whether he decides to use specific applications or interactive web which has been provided in smartphones and websites, he answered that he is less known and never used both of them. This is also the same for PS T3. Almost all of these observed pre-service teachers uphold the use of technological variants in the classroom, but they cannot show their support from their keen on using them for learning purposes. This enforces the belief in being a "digital native" does not necessarily incorporate those students with digital literacy, nor does it preclude "digital immigrants" from becoming technologically literate (Correy, 2012: 1). Even though they are the area of the digital age, they are still not being exposed to relevant input, whether it is the form of ideas that contribute to the designing of teaching with technology (Lei, 2009).

Likewise, the other case also goes for in-service teachers. IS T1 and IS T4 have a mindset which is implemented in the form of policy that the use of smartphones within internet connection is not allowed in the classroom. The view of IS T2 prompts that the use of textbooks rather than technology is sufficient to carry in class in teaching language. Moreover, IS T1 also believes that using realia (handmade media or sort of) is much more beneficial rather than using web (Padlet, Timeline, Canva). Even as their own handphones are facilitated with arrays of social media, the use of them remains as communication technology to spread information and keep friends close not more than that.

That phenomenon exists as in-service teachers were introduced later to technology (or even did not have access to technology) and challenged to the skills which could be adapted to the digital environment; or, they may have become cynical by the endless upgrades and changes to software and hardware. Koehler and Mishra (2008) pinpointed that teachers often have inadequate experience with using digital technologies for teaching and learning. He explained that many teachers got degrees when educational technology was at a very different stage of development than it is today. Thus, is not surprising that they do not appreciate its value or relevance to teaching and learning. Commenting on that occurrence, Dutt-Doner, et al. (2005: 62), stated that teachers need to understand the complexity of teaching in a technology-enriched environment because students bring different background knowledge and different technical skills to the classroom".

\section{Conclusion}

There is something in common between pre-service teachers and in-service teachers in this study that is the way in how to look at technological advances positively as it is brought into the classroom. If the both facets view technology as separate element in the teaching practice, not an integrated pedagogical constituent, whatever concepts lies in online learning whether it is digital learning, internet-based learning, electronic, or even virtual learning, the learning process which is supposed to incorporate technology within would find uneasy constraint to cope with, and the goal of learning would not be accelerated as it is expected in nature in the realm of the invention of technology.

\section{Acknowledgment}

I am grateful to Prof Fatchul Mu'in (The head of the Language Technical Service Unit in ULM (Lambung Mangkurat University)), who has provided insightful ideas and comments on an early version of this paper. I would also like to express my sincere and deep appreciation to Dr. Nanik Mariani (my colleague in Lambung Mangkurat University) for her patient, thorough and brilliant feedback on the completed version of the paper. 


\section{References}

Ally, M. (2004). Foundations of educational theory for online learning. In Terry (Ed.), The theory and practice of online learning, 3-31 ( $2^{\text {nd }}$ ed $)$. Athabasca, AB: Athabasca University.

Ash, K. (2011, February 22). Effective use of digital tools seen lacking in most tech.-rich schools: Education Week. Retrieved from http://www.edweek.org/ew/articles/2011/02/23/21 computing.h30.html?qs=katie+ash+effective+use+of +d igital+tools

Benson, A. (2002). Using online learning to meet workforce demand: A case study of stakeholder influence. Quarterly Review of Distance Education, 3(4), 443-452.

Brown, D. \& Warschauer, M. (2006). From the university to the elementary classroom: Students' experiences in learning to integrate technology in instruction. Journal of Technology and Teacher Education 14(3), 599-621.

Carliner, S. (1999). An overview of online learning (1st ed.). Armherst, MA: Human Resource Development Press

Carliner, S. (2004). An overview of online learning (2nd ed.). Armherst, MA: Human Resource Development Press

Chen, W., Lim, C., \& Tan, A. (2010). Pre-service teachers' ICT experiences and competencies: New generation of teacher in digital age. Retrieved August 19, 2019, from http://www.icce2010.upm.edu.my/papers/c6/full\%20paper/C6FP202.pdf

Conrad, D. (2002). Deep in the hearts of learners: Insights into the nature of online community. Journal of Distance Education, 17(1), 1-19.

Corey, R. C. (2012). Digital immigrants teaching digital natives: A phenomenological study of higher education faculty perspectives on technology integration with English core content (Doctoral dissertation, Drake University).

Dede, C. (2005). Planning for neomillennial learning styles. EDUCAUSE Quarterly 28(1). Retrieved August 18, 2019, from http://www.educause.edu

Dutt-Doner, K., Allen, S.M., \& Corcoran, D. (2005) Transforming student learning by preparing the next generation of teachers for type II technology integration. Computers in the Schools (22), 63-75.

Guha, S. (2002, February). Digital linkage: Factors related to elementary grade teachers' usage of computers in classroom instruction (Rep. - Research No. 143). Retrieved August 18, 2019, from http://www.eric.ed.gov/PDFS/ED438936.pdf

Kane, S.(n.d.). Generation $Y$. Retrieved June 27, 2019, fromAbout.com website: http://legalcareers.about.com/od/practicetips/a/GenerationY.htm?p=1

Khan, B.H. (1997) Web-based instruction: What is it and why is it? In: Khan, B.H., Ed., Web-Based Instruction. Educational Technology Publications, Englewood Cliffs, 5-18.

Khan, B. (2001). Web-based training. Englewood Cliffs, NJ: Educational Technology Publications.

Koehler, M. J. \& Mishra, P. (2008). Introducing TPCK. In AACTE committee on innovation and technology (Eds.), in Handbook of technological pedagogical content knowledge (TPCK) for educators (pp. 128), New York: Routledge.

Lei, J. (2009). Digital natives as pre service teachers: What technology preparation is needed? Journal of Computing in Teacher Education 25(3), 87-97.

Levine, A. (2010, October). Teacher education must respond to America. Kappan 2 (92), 19-24.

Manzo, K. K. (2009, April 3). Will digital natives revolutionize teaching? [Web log post]. Retrieved August 18, 2019, from Education Week's http://blogs.edweek.org/edweek/DigitalEducation/2009/04/will_digital_natives_revolutio html

Prensky, M. (2001, October). Digital natives, digital immigrants. On the Horizon, 9(5). Retrieved August 18, 2019, from http://www.albertomattiacci.it/docs/did/Digital_Natives_Digital_Immigrants.pdf

Prensky, M. (2005, December/January). Listen to the natives. Educational Leadership, 63(4), 8-13. 
Thielfoldt, D. \& Scheef, D. (2004, August). Generation X and the millennial: What you need to know about mentoring the new generations. Retrieved August 10, 2019, from http://www.abanet.ort/lpm/lpt/articles.mgt08044.html

Toledo, C. A. (2007). Digital culture: Immigrants and tourists responding to the natives' drumbeat. International Journal of Teaching and Learning in Higher Education, 19(1), 84-92. Retrieved August 10, 2019 from http://www.isetl.org/ijtlhe/pdf/IJTLHE152.pdf 